\title{
ERRATUM
}

\section{The patient experience}

\author{
Nadia Harbeck · Renate Haidinger
}

Published online: 13 December 2007

(C) Springer Science+Business Media, LLC. 2007

\section{Erratum to: Breast Cancer Res Treat (2007) 105(Suppl 1) DOI 10.1007/s10549-007-9703-8}

Due to an oversight, Financial Disclosure of the Authors in the above referenced supplement was not published as required. All authors have acknowledged and signed a

statement of Financial Disclosure/Conflict of Interest and certify that no honoraria for the work therein were received.

The online version of the original article can be found under doi:10.1007/s10549-007-9703-8.

N. Harbeck $(\bowtie) \cdot R$. Haidinger Frauenklinik der Technischen Universität München, Ismaninger Strasse 22, Munich 81675, Germany e-mail: nadia.harbeck@1rz.tum.de

R. Haidinger

Brustkrebs Deutschland e.V., Charles-de-Gaulle-Str. 6, Munich 81737, Germany 